\title{
Nature's own pharmacy: the diabetes perspective
}

\author{
BY ALISON M. GRAY* AND PETER R. FLATT
}

School of Biomedical Sciences, University of Ulster at Coleraine, Coleraine BT52 1SA

Since time immemorial man has looked to plants and their products as a source of innovative medicines. It is estimated that $66-80 \%$ of medicines used in developing countries are based on plants (Farnsworth, 1983) and $80 \%$ of the world's population relies on traditional medicines (Weragoda, 1980; Farnsworth, 1983). Within developed countries about $25 \%$ of medicines contain active principles derived from plants, and the majority of drugs in current use were developed following studies of traditional plant treatments (Day \& Bailey, 1988a). The present review considers the historical background and potential of plant remedies in the treatment of diabetes mellitus.

\section{TRADITIONAL PLANT TREATMENTS FOR DIABETES}

Before the discovery of insulin in the early 1920 s by Banting, Best, McCleod and Collip, and the later development of oral hypoglycaemic agents, the major form of treatment of diabetes mellitus involved dietary manipulation and the use of plant therapies. The recommended use of plants dates back to the Eber's papyrus of about $1550 \mathrm{BC}$. More than 400 plants worldwide have been documented for the treatment of diabetes and the majority await proper scientific and medical evaluation (Day \& Bailey, 1988b; Swanston-Flatt $e t$ al. 1991). Most of these traditional medicines are prepared from herbs, spices and plants which do not form part of the normal diet (Day \& Bailey, 1988a; Bailey \& Day, 1989). Some examples of these traditional plant treatments for diabetes are given in Table 1. However, several common components of the diet are traditionally recommended for regular consumption, and some are additionally taken as infusions, decoctions or alcoholic extracts. The World Health Organization has recommended accordingly that traditional plant treatments for diabetes warrant further evaluation (World Health Organization, 1980).

\section{THE DIABETOLOGIST'S PHARMACY NEEDS}

Approaches to the control of blood glucose and prevention of hyperglycaemia are central to the treatment of diabetes mellitus (Fig. 1). At present, none of these therapies either alone or in combination can reinstate normal blood glucose homeostasis, and many limitations exist in the use of anti-diabetic drugs. In insulin-dependent diabetes mellitus (IDDM) a more physiological means of insulin delivery is required. Despite attempts to develop new hypoglycaemic agents for non-insulin-dependent diabetes mellitus (NIDDM), only the $\alpha$ glucosidase ( $E C$ 3.2.1.20) inhibitor acarbose (Bay g5241; Bayer) has been added to the clinician's current choices of diet, sulphonylureas, metformin or insulin (Rachman \& Turner, 1995). New therapies are needed which reinstate a normal metabolic environment and prevent long-term complications. The development of new anti-diabetic drugs, which

*Present address: Department of Physiology and Pharmacology, University of Strathclyde, Glasgow G1 IXQ. 
Table 1. Examples of traditional plant treatments for diabetes mellitus

\begin{tabular}{|c|c|c|c|}
\hline Botanical name & Common name & Part of plant used & Reference \\
\hline \multicolumn{4}{|c|}{ Fruits } \\
\hline $\begin{array}{l}\text { Citrus limonium } \\
\text { Humulus lupulus } \\
\text { Juniperus communis } \\
\text { Optunia ficus-indica } \\
\text { Momordica charanita } \\
\text { Momordica charanita } \\
\text { Psidium guajava } \\
\text { Pyrus communis } \\
\text { Pyrus malus } \\
\text { Rubus fructicosus } \\
\text { Rubus idoeus } \\
\text { Sambucus nigra } \\
\text { Syzgium jambos } \\
\text { Tilia europa } \\
\text { Vaccinium mytillus }\end{array}$ & $\begin{array}{l}\text { Lemon } \\
\text { Hop } \\
\text { Juniper } \\
\text { Barbary fig } \\
\text { Cerasee (wild) } \\
\text { Karela (cultivated) } \\
\text { Guava } \\
\text { Pear } \\
\text { Apple } \\
\text { Blackberry } \\
\text { Raspberry } \\
\text { Elder } \\
\text { Java plum } \\
\text { Lime } \\
\text { Bilberry }\end{array}$ & $\begin{array}{l}\text { Fruit } \\
\text { Leaf } \\
\text { Berry } \\
\text { Leaf } \\
\text { Aerial parts } \\
\text { Fruit } \\
\text { Fruit } \\
\text { Leaf } \\
\text { Fruit } \\
\text { Leaf } \\
\text { Fruit } \\
\text { Flower } \\
\text { Fruit and seed } \\
\text { Fruit } \\
\text { Leaf }\end{array}$ & $\begin{array}{l}\text { Law (1970) } \\
\text { Peters (1957) } \\
\text { Palaiseul (1983) } \\
\text { Lewis (1949) } \\
\text { Ajgaonkar (1979) } \\
\text { Bailey et al. (1985) } \\
\text { Perry (1980) } \\
\text { Perry (1980) } \\
\text { Grieve (1976) } \\
\text { Farnsworth \& Segelman (1971) } \\
\text { Messegue (1981) } \\
\text { Lust (1986) } \\
\text { Mukerje (1953) } \\
\text { Palaiseul (1983) } \\
\text { Grieve (1976) }\end{array}$ \\
\hline \multicolumn{4}{|c|}{ Vegetables } \\
\hline $\begin{array}{l}\text { Allium cepa } \\
\text { Allium sativum } \\
\text { Brassica oleracea } \\
\text { Brassica rapa } \\
\text { Letuca sativa } \\
\text { Medicago sativa } \\
\text { Phaseolus vulgaris } \\
\text { Pisum sativum } \\
\text { Solanum tuberosum }\end{array}$ & $\begin{array}{l}\text { Onion } \\
\text { Garlic } \\
\text { Cabbage } \\
\text { Turnip } \\
\text { Lettuce } \\
\text { Lucerne } \\
\text { Haricot bean } \\
\text { Pea } \\
\text { Potato }\end{array}$ & $\begin{array}{l}\text { Bulb } \\
\text { Bulb } \\
\text { Leaf } \\
\text { Root } \\
\text { Leaf } \\
\text { Leaf } \\
\text { Pod } \\
\text { Seed } \\
\text { Tuber }\end{array}$ & $\begin{array}{l}\text { Bever \& Zahnd (1979) } \\
\text { Lewis (1949) } \\
\text { Farnsworth \& Segelman (1971) } \\
\text { Farnsworth \& Segelman (1971) } \\
\text { Lewis (1949) } \\
\text { Lust (1986) } \\
\text { Lewis (1949) } \\
\text { Lewis (1949) } \\
\text { Palaiseul (1983) }\end{array}$ \\
\hline \multicolumn{4}{|c|}{ Herbs and spices } \\
\hline $\begin{array}{l}\text { Agrimony eupatoria } \\
\text { Arctium lappa } \\
\text { Artemisia dracunculus } \\
\text { Capsicum fructescens } \\
\text { Coriandrum sativum } \\
\text { Eucalyptus globulus } \\
\text { Galega officinalis } \\
\text { Glycyrrhiza glabra } \\
\text { Panax ginseng } \\
\text { Salvia officinale } \\
\text { Taraxacum officinale } \\
\text { Thymus vulgaris } \\
\text { Trigonella foenum-graecum } \\
\text { Urtica diocia } \\
\text { Viscum album } \\
\text { Zingiber officinale }\end{array}$ & $\begin{array}{l}\text { Agrimony } \\
\text { Burdock } \\
\text { Tarragon } \\
\text { Chile pepper } \\
\text { Coriander } \\
\text { Eucalyptus } \\
\text { Goat's rue } \\
\text { Liquorice } \\
\text { Ginseng } \\
\text { Sage } \\
\text { Dandelion } \\
\text { Thyme } \\
\text { Fenugreek } \\
\text { Nettle } \\
\text { Mistletoe } \\
\text { Ginger }\end{array}$ & $\begin{array}{c}\text { Leaf } \\
\text { Leaf } \\
\text { Leaf } \\
\text { Seed } \\
\text { Seed } \\
\text { Leaf } \\
\text { Leaf } \\
\text { Root } \\
\text { Root } \\
\text { Leaf } \\
\text { Root and leaf } \\
\text { Leaf } \\
\text { Seed } \\
\text { Aerial parts } \\
\text { Leaf and stem } \\
\text { Root }\end{array}$ & $\begin{array}{l}\text { Lewis (1949) } \\
\text { Lewis (1949) } \\
\text { Duke (1985) } \\
\text { Farnsworth \& Segelman (1971) } \\
\text { Farnsworth \& Segelman (1971) } \\
\text { Lewis (1949) } \\
\text { Bunney (1984) } \\
\text { Grieve (1976) } \\
\text { Lewis (1949) } \\
\text { Atkinson (1979) } \\
\text { Peters (1957) } \\
\text { Duke (1985) } \\
\text { Ajgaonkar (1979) } \\
\text { Lewis (1949) } \\
\text { Peters (1957) } \\
\text { Famsworth \& Segelman (1971) }\end{array}$ \\
\hline \multicolumn{4}{|c|}{ Mushrooms and Fungi } \\
\hline $\begin{array}{l}\text { Agaricus bisporus } \\
\text { Agaricus campestris } \\
\text { Amanita phalloides } \\
\text { Amanita verna } \\
\text { Amanita virosa } \\
\text { Coprinus comatus }\end{array}$ & $\begin{array}{l}\text { Edible button mushroom } \\
\text { Edible field mushroom } \\
\text { Fool's mushroom } \\
\text { Destroying angel } \\
\text { Death cap } \\
\text { Ink cap }\end{array}$ & $\begin{array}{l}\text { Fruiting body } \\
\text { Fruiting body } \\
\text { Fruiting body } \\
\text { Fruiting body } \\
\text { Fruiting body } \\
\text { Fruiting body }\end{array}$ & $\begin{array}{l}\text { Ahmad et al. }(1984) \\
\text { Ewart et al. (1975) } \\
\text { Lewis (1949) } \\
\text { Potron (1956) } \\
\text { Potron (1956) } \\
\text { Kronberger (1964) }\end{array}$ \\
\hline \multicolumn{4}{|c|}{ Yeast } \\
\hline Saccharomyces cerevisiae & Brewer's yeast & Cell extract & Collip (1923) \\
\hline
\end{tabular}




\section{Inhibitors of gluconeogenesis and g/ycogenolysis e.g. sulphonylureas, metformin, thiazolidinediones, nicotinic acid}

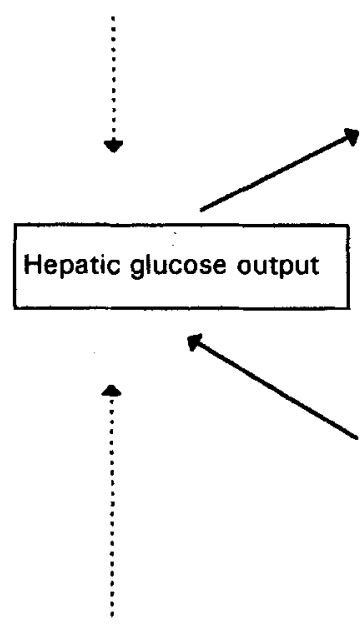

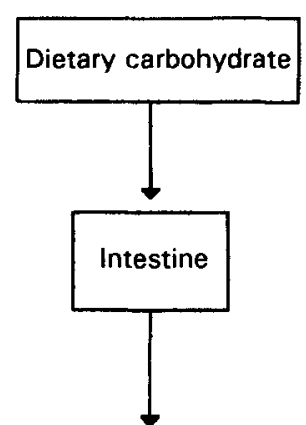
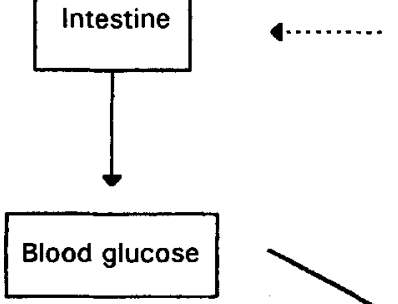

Inhibitors of digestion

e.g. $\alpha$-glucosidase inhibitors, guar gum other polysaccharides

Insulin secretagogues

e.g. sulphonylureas
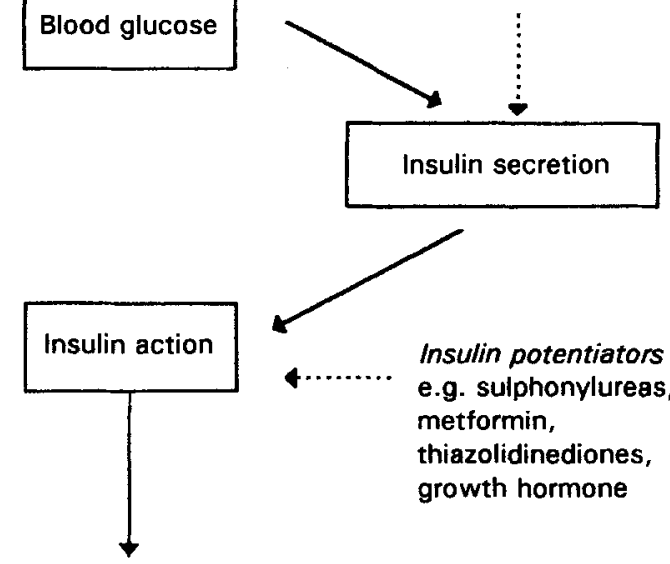

Insulin potentiators e.g. sulphonylureas, metformin, thiazolidinediones, growth hormone

Appetite suppressants antiobesity agents (fenfluramine)

Insulin mimetics

e.g. incretins thiazolidinediones, trace elements (Zn, Mn, Cr, Mg), vanadium compounds
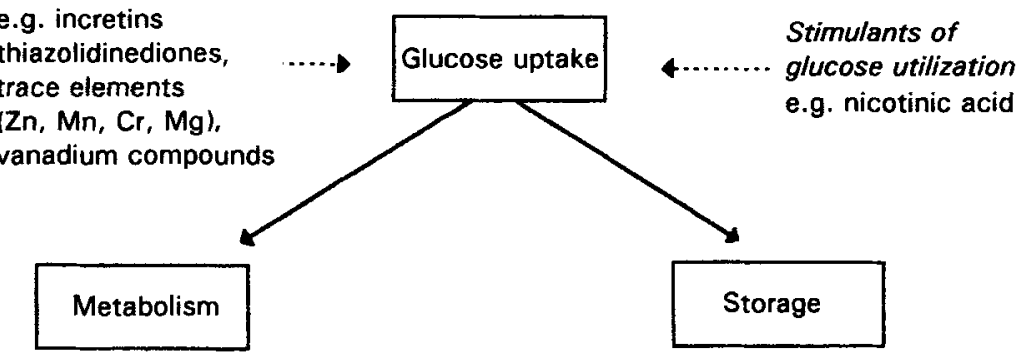

Fig. 1. Approaches to the control of hyperglycaemia. $\alpha$-Glucosidase, EC 3.2.1.20. (Adapted from Bailey \& Flatt, 1995).

address the underlying metabolic lesions in NIDDM, ideally requires new pharmacological treatments which stimulate both the secretion and the action of insulin (Bailey \& Flatt, 1995).

\section{HYPOGLYCAEMIC AGENTS FROM PLANTS}

With few exceptions, traditional plant treatments for diabetes have not claimed to be alternatives to insulin therapy in IDDM. Isolated reports have described plant-derived materials that exert an insulin-like effect in IDDM (Chandola \& Tripathl, 1981; Khanna et al. 1981). However, these reports have not been independently evaluated, and there is no evidence that they could provide a long-term botanical substitute for insulin. A small 
Table 2. Purported hypoglycaemic chemicals from plant sources

(Compiled from Bever \& Zahnd, 1979; Duke, 1985; Ling-Hua \& Pei-Gen, 1993)

\begin{tabular}{|c|c|c|}
\hline Aconitan A-D (glycans) & Ganoderan A \& B & Nicotinamide \\
\hline Allican (diallyl disulphide & (glycans) & Obaculactone \\
\hline oxide) & Ginsenin & Oxypeudedanin \\
\hline Allylpropyl disulphide (APDS) & Ginsenoside $\mathrm{Rb}_{2}$ & Panacem \\
\hline Amellin & Guanidine & Panaquellin \\
\hline Ammeran A-D (glycans) & Gymnemic acid & Panax acid \\
\hline Antimellin & Hypoglycin A & Panaxan A-E \\
\hline Atractan A-C (glycans) & ( $\alpha$-amino-2-cyclo-propylpropionic acid) & (peptidoglycans) \\
\hline B-sitosterol-D-glucoside & & Phallacin \\
\hline Bassic acid & Hypoglycin B & Phallacidin \\
\hline Bengalenoside & $(\gamma$-glutamyl-hypoglycin A) & Phalloidin \\
\hline Berberine & Inulin & Phaseolan \\
\hline Catharathine & Kampferol & 2-Propenyl-disulphide \\
\hline Charantin (momordicin) & Khellin & Puerarin \\
\hline Clauseanacoumarine & Lepidin & Quercitin \\
\hline Coixol & Leurosine & Rutin \\
\hline Coumarin & Lithosperman A-C & Saccharan A-F (glycans) \\
\hline Diallyl trisulphide & (glycans) & Scopoletin \\
\hline Dioscoran A-F (glycans) & Lochnerine & Tecomine \\
\hline Diphenylamine & Lupanine & Tecostamine \\
\hline Emeriamine (R-3-acetylamine- & Matrine & Tecostamine-B-sitosterol \\
\hline 4-trimethylaminobutyric acid) & Momordicin (charantin) & Tetrahydroalstonine \\
\hline Eritadenine & Myricetin & Trigonelliine \\
\hline Ephedran A-E (glycans) & Mytillin & Urticin \\
\hline Epicatechin & N-methylnicotinic acid & Vegulin \\
\hline Foetidin & Neomyrtillin & Vindoline \\
\hline Forskolin & (7-methyl-delphinidin) & Vindolinine \\
\hline Galegine & Nicotinic acid & \\
\hline
\end{tabular}

number of review articles exist which document hypoglycaemic agents derived from plant treatments for diabetes (e.g. Bever \& Zahnd, 1979; Duke, 1985; Day, 1990; Ling-Hua \& Pei-Gen, 1993). Several anti-diabetic plants have shown sufficient hypoglycaemic activity to warrant at least partial characterization of the active principle (Table 2). Many traditional plant treatments owe their folklore reputation, at least in part, to the presence of polysaccharides, which achieve beneficial effects through reduction of gastointestinal processing and postprandial hyperglycaemia. Plants which have yielded anti-diabetic polysaccharides are shown in Table 3 . However, for the majority of traditional plant treatments the active principles present together with their mode of action have yet to be characterized (Ajgaonkar, 1979; Day \& Bailey, 1988a). Hypoglycaemic compounds from plants that help directly combat insulin resistance and/or promote endogenous insulin release are realistic possibilities.

\section{CELLULAR MECHANISMS OF ACTION}

A few comprehensive studies of traditional anti-diabetic plants have been carried out (Swanston-Flatt et al. 1989a,b, 1990a). The anti-hyperglycaemic actions of thirty-seven European plants traditionally used as adjuncts to the treatment of diabetes were investigated using streptozotocin-treated mice and $d b / d b$ mice (Swanston-Flatt et al. $1990 \mathrm{~b}$ ). A number of plants tested were found to have variable beneficial effects (Swanston-Flatt et al. 1990b). The mechanism of action of aqueous extracts of a number of 


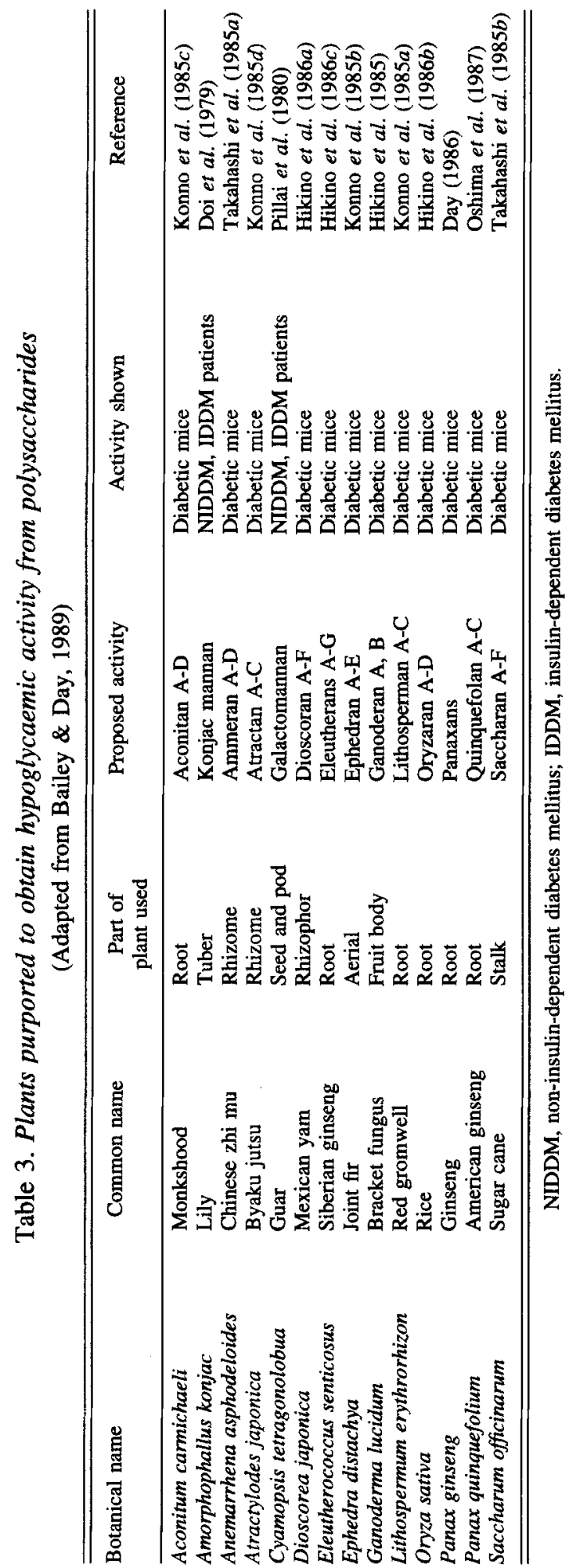


Table 4. Mechanism of action of traditional plant treatments for diabetes

\begin{tabular}{|c|c|c|c|c|}
\hline Common name & Botanical name & Part used & Extra-pancreatic effect & Pancreatic effect \\
\hline Agrimony & Agrimony eupatoria & Leaf & $\sqrt{ }$ & $\sqrt{ }$ \\
\hline Coriander & Coriandrum sativum & Seed & $\sqrt{ }$ & $J$ \\
\hline Elder & Sambucus nigra & Flower & - & $\sqrt{ }$ \\
\hline Eucalyptus & Eucalyptus globulus & Leaf & $J$ & $j$ \\
\hline Juniper & Juniperus communis & Dried berry & - & $?$ \\
\hline Lucerne & Medicago sativa & Leaf & $\sqrt{ }$ & $J$ \\
\hline Mistletoe & Viscum album & Leaf and stem & - & $J$ \\
\hline Mushroom & Agaricus campestris & Fruiting body & $\sqrt{ }$ & $J$ \\
\hline
\end{tabular}

$J$, beneficial (enhancing) effect; -, not investigated; ?, effect queried.

these plants has recently been investigated. At the cellular level, plants could elicit beneficial anti-hyperglycaemic effects via extra-pancreatic and/or pancreatic actions. Aqueous plant extracts, prepared by methods similar to those used in previous animal studies, were investigated for possible extra-pancreatic and/or pancreatic effects. Glucose uptake and metabolism by abdominal muscle isolated from weanling mice was used to evaluate the extra-pancreatic potential of plant extracts. Insulin-secreting BRIN-BD11 cells (McClenaghan et al. 1996) were used to investigate the possible pancreatic actions of plant extracts. Aqueous extracts of agrimony (Agrimony eupatoria), lucerne (Medicago sativa), coriander (Coriandrum sativum) and edible mushroom (Agaricus campestris) enhanced insulin secretion and mimicked the effect of insulin on glucose metabolism in vitro (Gray et al. 1994; Gray \& Flatt, 1994, 1996, 1997). Such dual pancreatic and extra-pancreatic actions would prove to be an important advance on existing therapies used to treat and control diabetes, such as oral hypoglycaemic drugs (which act either by enhancing insulin secretion or by improving the action of insulin). Findings for these and additional plant extracts are outlined in Table 4.

\section{INHERENT DIFFICULTIES WITH STUDIES}

Discrepancies do arise between findings reported in the literature. Juniper (Juniperus communis) berries have in the past been documented as a traditional remedy for diabetes (Palaiseul, 1983) and serve as an illustration of the inherent difficulties encountered when examining data to hand. Juniper reduced loss of body weight, decreased polydipsia and countered the early hyperglycaemia of streptozotocin-treated mice (Swanston-Flatt et al. 1990a). A significant dose-dependent hypoglycaemic effect has been reported in normoglycaemic rats, and weight gain in chronic treatment of streptozotocin-diabetic rats administered a decoction of juniper berries (DeMedina et al. 1994). However, more recent studies in streptozotocin-treated mice failed to show an anti-hyperglycaemic effect and, if anything, polydipsia and glycaemia worsened with juniper treatment (Fig. 2). A confounding factor in all these studies is the difficulty in making direct comparisons between them. Sensitivity to streptozotocin varies with species, strain, sex, age and nutritional state (Bailey \& Flatt, 1991). In general terms, animals in the studies of DeMedina et al. (1994) received approximately a 10 -fold greater amount of juniper when compared with results of our studies (Fig. 2) or those of Swanston-Flatt et al. (1990a). Juniper berries vary in their content of volatile oil $(2-34 \mathrm{~g} / \mathrm{kg})$ depending on the geographical location, altitude, degree of ripeness and other factors (Duke, 1985). Anti- 

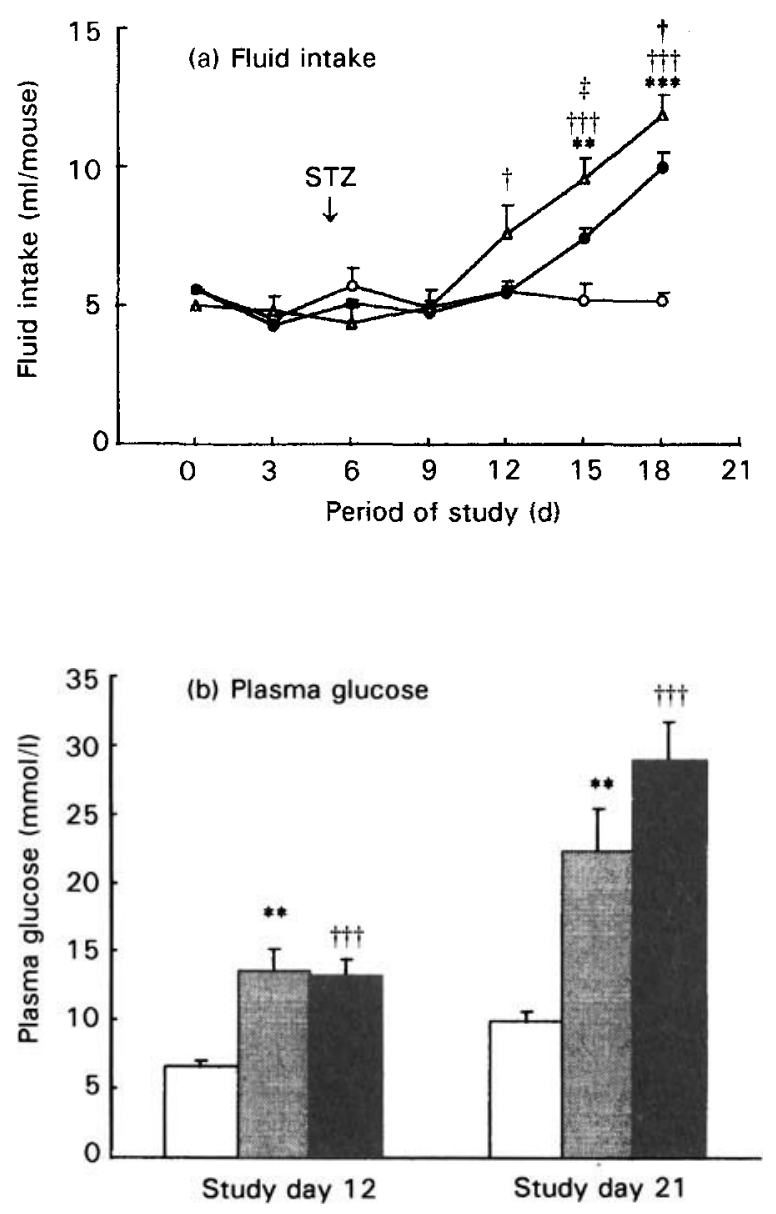

Fig. 2. Effect of juniper (Juniperus communis) on streptozotocin (STZ)-treated mice on (a) fluid intake and (b) nonfasting plasma glucose concentrations. Juniper was administered for $21 \mathrm{~d}(62.5 \mathrm{~g} / \mathrm{kg}$ feed, $1 \mathrm{~g} / 400 \mathrm{ml}$ in place of drinking water) ad libitum. STZ was administered to non-fasting animals on study day $5(200 \mathrm{mg} / \mathrm{kg}$ intraperitoneally). Treatment groups were: normal mice receiving normal diet $(-O-, \square)$, STZ mice receiving normal diet (-O-, 圆), STZ mice receiving juniper $(-\leftarrow, \mathbf{E})$. Values are means with their standard errors represented by vertical bars for groups of five to eight adult male mice. Mean values for STZ mice were significantly different from those for normal mice at the same time point. ${ }^{* *} P<0.01,{ }^{* * * P}<0.001$; mean values for STZ mice receiving juniper were significantly different from those for normal mice at the same time point: $+P<0.05,+\dagger+P<0.001$; mean values for STZ mice receiving juniper were significantly different from those for STZ mice at the same time point: $\$ P<0.05$.

diabetic components in this plant may be variable from one batch to the next and may explain previous favourable findings for this plant. Recent studies examined the possible pancreatic action of juniper (Table 4). The insulin-releasing potential of an aqueous extract of juniper was evaluated using insulin-secreting BRIN-BD11 cells (Fig. 3). The increase at $10 \mathrm{mg} / \mathrm{ml}$ appears to be an artefact of this experimental situation, since at this concentration the extract is toxic to the cells. DeMedina et al. (1994) reported an increase in glucose uptake by rat diaphragm at doses equivalent to $0.1 \mathrm{mg} / \mathrm{ml}$, but this has yet to be independently evaluated. 


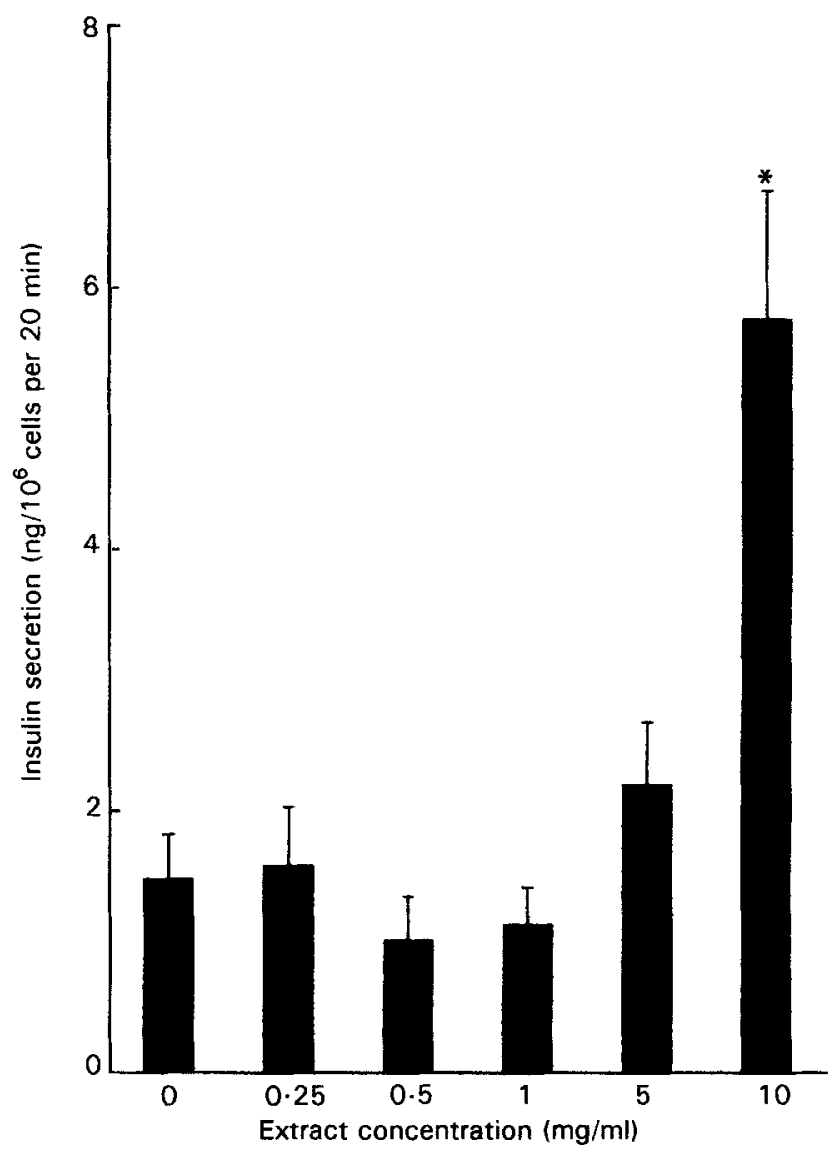

Fig. 3. Effect of aqueous extract of juniper (Juniperus communis) berries on insulin secretion by BRIN-BD11 cells. Extract was produced by 15 min hot infusion (ground plant material placed in boiling water, covered, removed from heat and allowed to stand for $15 \mathrm{~min}$ before being filtered). Values are means with their standard errors represented by vertical bars for four to six independent observations. Mean values were significantly different from those for control incubations performed without extract: $* P<0.001$.

\section{FROM PLANT TO PHARMACY}

Besides providing active raw materials, plants can offer molecules that serve as templates for the development of new drugs. Goat's rue (Galega officinalis), used in Europe as a treatment for diabetes since medieval times, yields a hypoglycaemic principle rich in guanidine (Bailey, 1985). Further derivatives of this principle have given rise to biguanides and the present anti-diabetic agent, metformin (Sterne, 1969). A balanced approach to traditional plant treatments for diabetes is required which allows for proper scientific and medical evaluation together with cautious optimism in the face of sometimes conflicting scientific evidence.

\section{CONCLUDING THOUGHTS}

The rapidly increasing prevalence of diabetes mellitus in many parts of the world, coupled with increasing life expectancy and related demographic changes, will continue to 
challenge the resourcefulness of scientists and clinicans in refining existing therapies and developing new approaches to counter diabetes mellitus (Bailey \& Flatt, 1995). Given the large number of plants and plant extracts reputed to possess anti-diabetic properties (Day, 1990), few have received equitable scientific and medical scrutiny, and only a small number of purportedly-active compounds have been wholly or partially characterized. The scope for the discovery and development of new anti-diabetic therapies from nature's pharmacy is vast and merits corresponding consideration.

A.M.G. was supported by the Department of Health and Social Services, Northern Ireland.

\section{REFERENCES}

Ahmad, N., Khan, M. M., Rastogi, A. K. \& Kidwai, J. R. (1984). Effect of age on Agaricus bisporus PHA-B stimulated insulin release and ${ }^{45} \mathrm{Ca}^{2+}$ uptake in vitro by islets of Langerhans. Acto Diabetologia Latina 21, 349-355.

Ajgaonkar, S. S. (1979). Herbal drugs in the treatment of diabetes. International Diabetes Federation Bulletin 24, 10-17.

Atkinson, M. (1979). Herbs for Your Health. New York: Dalesman Books.

Bailey, C. J. (1985). The anti-hyperglycaemic action of metformin. In Diabetes and Metformin. A Research and Clinical Update, pp. 17-26 [H. M. J. Krans, editor]. London: Royal Society of Medicine.

Bailey, C. J. \& Day, C. (1989). Traditional plant medicines as treatments for diabetes. Diabetes Care 12, 553564.

Bailey, C. J., Day, C. \& Leatherdale, B. A. (1985). Cerasee, a traditional treatment for diabetes. Studies in normal and streptozotocin diabetic mice. Diabetes Research 2, 81-84.

Bailey, C. J. \& Flatt, P. R. (1991). Animal models of non-insulin-dependent diabetes mellitus. In Textbook of Diabetes, pp. 228-239 [J. C. Pickup and G. Williams, editors]. London: Blackwell Scientific Publications.

Bailey, C. J. \& Flatt, P. R. (1995). Development of antidiabetic drugs. In Drugs, Diet and Disease, vol. 2, Mechanistic Approaches to Diabetes, pp. 279-326 [C. Iaonnides and P. R. Flatt, editors]. London: Ellis Horwood.

Bever, B. O. \& Zahnd, G. R. (1979). Plants with oral hypoglycaemic action. Quarterly Journal of Crude Drug Research 17, 139-196.

Bunney, C. (1984). The Illustrated Book of Herbs. Their Medicinal and Culinary Uses. London: Octopus.

Chandola, H. M. \& Tripathl, S. N. (1981). Hypoglycaemic response to $C$. tamala in diabetes. Abstracts of Second World Congress on Diabetes in the Tropics and Developing Countries, Bombay, Abstr 80.

Collip, J. B. (1923). Glucokinin. A new hormone present in plant tissue. Journal of Biological Chemistry 56, 513-543.

Day, C. (1986). Guar gum. Industrial Biotechnology 6, 137-138.

Day, C. (1990). Hypoglycaemic compounds from plants. In New Antidiabetic Drugs, pp. 267-278 [C. J. Bailey and P. R. Flatt, editors]. London: Smith-Gordon.

Day, C. \& Bailey, C. J. (1988a). A diabetologist's herbal. Royal Society of Medicine, Current Medical Literature -Diabetes 5, 31-35.

Day, C. \& Bailey, C. J. (1988b). Hypoglycaemic agents from traditional plant treatments for diabetes. International Industrial Biotechnology 8, 5-8.

DeMedina, F. S., Gamez, M. J., Jimenez, I., Osuna, J. I. \& Zarzuelo, A. (1994). Hypoglycaemic activity of juniper 'berries'. Planta Medica 60, 197-200.

Doi, K., Matsuura, M., Kawara, A. \& Baba, S. (1979). Treatment of diabetes with glucomannan (konjac mannan). Lancet i, 987-988.

Duke, J. A. (1985). Handbook of Medicinal Herbs. Boca Raton, FL: CRC Press.

Farnsworth, N. R. (1983). The role of medicinal plants in drug development. In Natural Products and Drug Development, pp. 17-30 [P. Krogsgaard-Larsen, S. Brogger-Christensen and S. Kofod, editors]. Copenhagen: Munksgaard.

Farnsworth, N. R. \& Segelman, A. B. (1971). Hypoglycaemic plants. Tile and Till 57, 52-55.

Ewart, R. B. L., Kornfeld, S. T. \& Kipnis, D. M. (1975). Effect of lectins on hormone release from isolated rat islets of Langerhans. Diabetes 24, 705-714.

Gray, A. M., Day, C. \& Flatt, P. R. (1994). Investigation of the antihyperglycaemic and insulin-releasing effects of Medicago sativa. Diabetic Medicine 11, S20.

Gray, A. M. \& Flatt, P. R. (1994). Evaluation of the antidiabetic effects of an edible mushroom (Agaricus campestris). Proceedings of the Nutrition Society 53, 125A. 
Gray, A. M. \& Flatt, P. R. (1996). Investigation of the efficacy and mode of action of the traditional anti-diabetic plant, Agrimony eupatoria. Diabetic Medicine 13, S30.

Gray, A. M. \& Flatt, P. R. (1997). Evaluation of the antidiabetic effects of coriander (Coriandrum sativum). Proceedings of the Nutrition Society 56, 45A.

Grieve, M. (1976). A Modern Herbal. Harmondsworth: Penguin.

Hikino, H., Konno, C., Miriu, Y. \& Hayashi, T. (1985). Isolation and hypoglycaemic activity of ganoderans A and B, glycans of Ganoderma lucidum fruit bodies. Planta Medica 51, 339-340.

Hikino, H., Konno, C., Takahashi, M., Murakami, M., Kato, Y., Karikure, M. \& Hayashi, T. (1986a). Isolation and hypoglycaemic activity of discoran A, B, C, D, E and F: glycans of Discorea japonica rhizophors. Planta Medica 52, 168-171.

Hikino, H., Murakami, M., Oshima, Y. \& Konno, C. (1986b). Isolation and hypoglycaemic activity of oryzarans A, B, C and D, glycans of Oryza sativa roots. Planta Medica 52, 490-492.

Hikino, H., Takahashi, M., Otake, K. \& Konno, C. (1986c). Antidiabetic drugs 20: isolation and hypoglycaemic activity of eleutheran-A, eleutheran-B, eleutheran-C, eleutheran-D, eleutheran-E, eleutheran-F and eleutheran-G: glycans of Eleurtherococcus senticosus roots. Journal of Natural Products 49, 293-295.

Khanna, P., Jain, S. C., Panagiriya, A. \& Dixit, V. P. (1981). Hypoglycaemic activity of polypeptide-p from a plant source. Journal of Natural Products 44, 648-655.

Konno, C., Mizuno, T. \& Hikino, H. (1985a). Isolation and hypoglycaemic activity of lithospermans A, B and C, glycans of Lithospermum erythrorhizon roots. Planta Medica 51, 157-158.

Konno, C., Mizuno, T. \& Hikino, H. (1985b). Isolation and hypoglycaemic activity of ephedrans A, B, C, D and E, glycans of Ephedra distachya herbs. Planta Medica 51, 162-163.

Konno, C., Morayana, M., Sugiyama, K., Arai, M., Murakami, M., Takahashi, M. \& Hikino, H. (1985c). Isolation and hypoglycaemic activity of aconitans A, B, C and D, glycans of Aconitum carmichaeli roots. Planta Medica 51, 160-161.

Konno, C., Suzuki, Y., Oishi, K., Munakata, E. \& Hikino, H. (1985d). Isolation and hypoglycaemic activity of atractans A, B and C, glycans of Atractylodes japonica rhizomes. Planta Medica 51, 102-103.

Kronberger, K. (1964). Pilze und Diabetes (Fungi and diabetes). Bericht Naturwiss Gesellsch Bayreuth 11, 231235.

Law, D. (1970). Herbs for Cooking and for Healing. London: Foulsnam.

Lewis, J. J. (1949). Diabetes and the insulin administration problem. Physiological Reviews 29, $75-90$.

Ling-Hua, Z. \& Pei-Gen, X. (1993). Recent advances in studies of antihyperlipidaemic and antihyperglycaemic compounds from Chinese traditional and herbal medicines. Phytotherapy Research 7, 217-226.

Lust, J. (1986). The Herb Book. Reading: Bantam Books, Cox and Wyman.

McClenaghan, N. H., Barnett, C. R., Ah-Sing, E., Abdel-Wahab, Y. H. A., O'Harte, F. P. M., Yoon, T-W, Swanston-Flatt, S. K. \& Flatt P. R. (1996). Characterization of a novel glucose-responsive insulin-secreting cell line, BRIN-BD11, produced by electrofusion. Diabetes $45,1132-1140$.

Messegue, M. (1981). Health Secrets of Plants and Herbs. London: Pan Books.

Mukerje, B. (1953). Indian Pharmaceutical Codex, vol. 1, p. 127. New Delhi, India: Indian Pharmaceutical Society.

Oshima, Y., Sato, K. \& Hikino, H. (1987). Isolation and hypoglycaemic activity of quinquefolans A, B and C, glycans of Panax quinquefolium roots. Journal of Natural Products 50, 188-190.

Palaiseul, J. (1983). Grandmother's Secrets. Her Green Guide to Health from Plants. Reading: Penguin Books, Cox and Wyman.

Perry, L. M. (1980). Medicinal Plants of East and Southeast Asia. Attributed Properties and Uses. Cambridge, MA: The MIT Press.

Peters, G. (1957). Ubersichten Insulin-Ersatzmittel pflanzlichen Ursprungs (Review of insulin substitutes from vegetable sources). Deutsch Medizin Wochenschrift 82, 320-322.

Pillai, N. R., Seshadri, C. \& Santhakumari, G. (1980). Hypoglycaemic effect of Cyamopsis tetragonoloba taub (gowar). Indian Journal of Medical Research 72, 128-131.

Potron, M. (1956). Champignons et diabete (Mushrooms and diabetes). Concours Medical 36, 3795-3796.

Rachman, J. \& Turner, R. C. (1995). Drugs on the horizon for treatment of type 2 diabetes. Diabetic Medicine $12,467-478$

Sterne, J. (1969). Pharmacology and mode of action of the hypoglycaemic guanidine derivatives. In Pharmacology and Mode of Action of the Hypoglycaemic Guanidine Derivatives, pp. 193-245 [G. D. Campbell, editor]. New York: Academic Press.

Swanston-Flatt, S. K., Day, C., Bailey, C. J. \& Flatt, P. R. (1989a). Evaluation of traditional plant treatments for diabetes: studies in streptozotocin diabetic mice. Acta Diabetologia Latina 26, 51-55.

Swanston-Flatt, S. K., Day, C., Bailey, C. J. \& Flatt, P. R. (1990a). Traditional plant treatments for diabetes. Studies in normal and streptozotocin diabetic mice. Diabetologia 33, 462-464.

Swanston-Flatt, S. K., Day, C., Flatt, P. R. \& Bailey, C. J. (1990b). Evaluation of the antihyperglycaemic properties of traditional plant treatments for diabetes in streptozotocin-diabetic and $\mathrm{db} / \mathrm{db}$ mice. In Frontiers in Diabetes Research. Lessons from Animal Diabetes, vol. 3, pp. 286-293 [E. Shafrir, editor]. London: SmithGordon. 
Swanston-Flatt, S. K., Day, C., Flatt, P. R., Gould, B. J. \& Bailey, C. J. (1989b). Glycaemic effects of traditional European plant treatments for diabetes. Studies in normal and streptozotocin diabetic mice. Diabetes Research 10, 69-73.

Swanston-Flatt, S. K., Flatt, P. R., Day, C. \& Bailey, C. J. (1991). Traditional dietary adjuncts for the treatment of diabetes mellitus. Proceedings of the Nutrition Society 50, 641-651.

Takahashi, M., Konno, C. \& Hikino, H. (1985a). Isolation and hypoglycaemic activity of anemarans A, B, C and D, glycans from Anemarrhena asphodeloides rhizomes. Planta Medica 51, 100-102.

Takahashi, M., Konno, C. \& Hikino, H. (1985b). Isolation and hypoglycaemic activity of saccharans A, B, C, D, $\mathrm{E}$ and F, glycans of Saccharum officinarium stalks. Planta Medica 51, 258-260.

Weragoda, P. B. (1980). Some questions about the future of traditional medicine in developing countries. Joumal of Ethnopharmacology 2, 193-194.

World Health Organization (1980). World Health Organization Expert Committee on Diabetes Mellitus. Second Report. Technical Report Series no. 646. Geneva: WHO. 